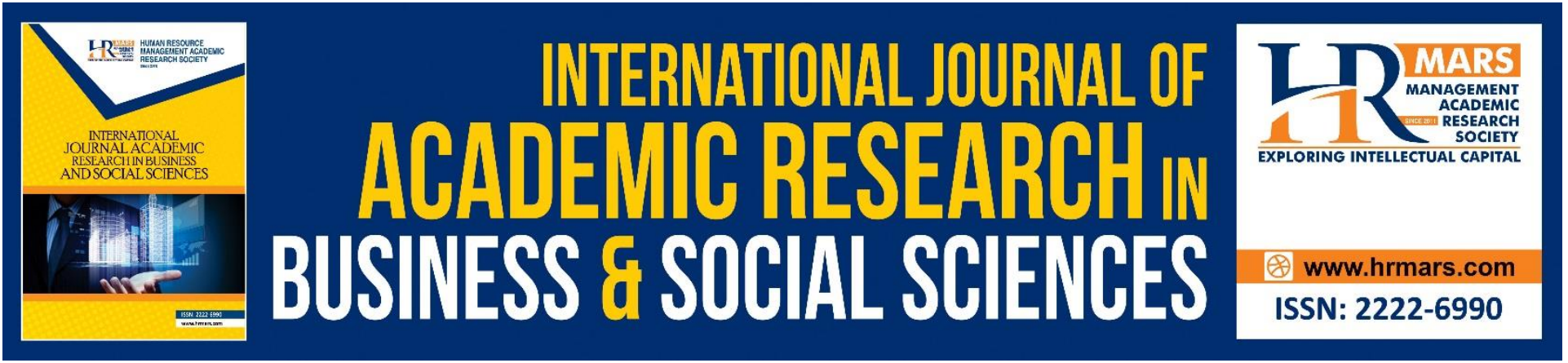

\title{
Enhancing Writing Skill among the Low Achiever Using Peer and Self-Assessment Practice in ESL Classroom
}

\author{
Norhafilah Abdullah, Md. Nasir Masran
}

To Link this Article: http://dx.doi.org/10.6007/IJARBSS/v11-i7/10526

DOI:10.6007/IJARBSS/v11-i7/10526

Received: 15 May 2021, Revised: 18 June 2021, Accepted: 30 June 2021

Published Online: 29 July 2021

In-Text Citation: (Abdullah \& Masran, 2021)

To Cite this Article: Abdullah, N., \& Masran, M. N. (2021). Enhancing Writing Skill among the Low Achiever Using Peer and Self-Assessment Practice in ESL Classroom. International Journal of Academic Research in Business and Social Sciences, 11(7), 681-690.

Copyright: @ 2021 The Author(s)

Published by Human Resource Management Academic Research Society (www.hrmars.com) This article is published under the Creative Commons Attribution (CC BY 4.0) license. Anyone may reproduce, distribute, translate and create derivative works of this article (for both commercial and non-commercial purposes), subject to full attribution to the original publication and authors. The full terms of this license may be seen at: http://creativecommons.org/licences/by/4.0/legalcode

Vol. 11, No. 7, 2021, Pg. 681 - 690

Full Terms \& Conditions of access and use can be found at http://hrmars.com/index.php/pages/detail/publication-ethics 


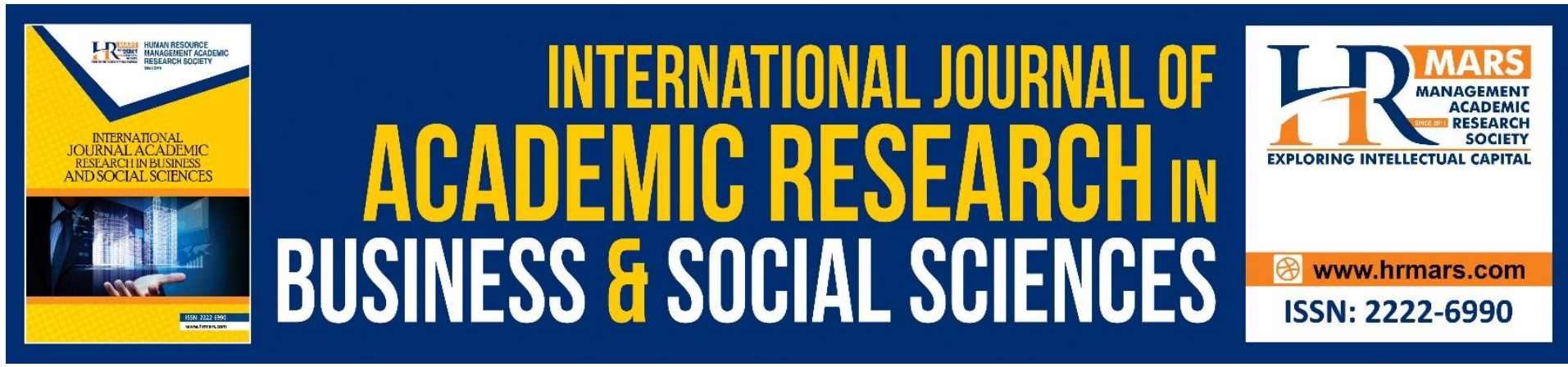

\title{
Enhancing Writing Skill among the Low Achiever Using Peer and Self-Assessment Practice in ESL Classroom
}

\author{
Norhafilah Abdullah, Md. Nasir Masran \\ Faculty of Human Development, Universiti Pendidikan Sultan Idris, 35900 Tanjong Malim, \\ Perak, Malaysia
}

\begin{abstract}
This paper aimed at exploring and recognizing how self-assessment and peer feedback could help the low achiever students resolve their weaknesses in second language writing skills. Introducing peer and self- assessment approaches into English teaching may be quite challenging but beneficial to strengthening the relationship between teacher feedback and students learning, encouraging student to change the way of students learning and promote lifelong learning. The study proposed a writing module based on self-regulation model which emphasis on self and assessment practice in English Language classroom. The implementation is expected to help students improve their writing skills, social interactions as well as arousing their interest in learning English. The outcome of the proposed module is also hoped to create a more meaningful English lessons rather than the surface level approach of teaching by rote memorization and repetition.
\end{abstract}

Keywords: Self-Peer Assessment, Self-Regulation Practice, Writing in ESL, Low Achieve

\section{Introduction}

Language is important because it is one of the essential ways of communicating and socializing with others around us. As the official language of 53 countries and spoken by around 400 million people, English has become the world's second-largest language. The data from Internet World Stats (2017) showed 872.9 million internet users speak English and makes up $25.9 \%$ of the global online population. Fluency in speaking and writing in the language will not only give one's access to the world of entertainment but to be more knowledgeable and create many opportunities to achieve the highest potential of the individual; while lack of language comprehension places non-English speaking people at a disadvantage position, underemployed, less future prospect than those who understand and proficient in the language (Wilkins, 2014; Rios, 2014).

English is considered as one of the alien subjects for some students especially the low achievers as they did not have much opportunity to practice and some never apply the language outside the classroom (Rajkamal \& Prema, 2018; Misbah, 2017; Norsimah, 2008; Kelly, 2003). According to Misbah, Mohamad, Yunus \& Yaacob (2017), the lack of English 
vocabulary, first language influence and the socio-economic status of the family are three major factors contributing to students' difficulties in the English Language (EL) learning. All the factors mentioned above are closely related with the background of the low achiever learner which mostly contributing in the failure percentage. Most of them received lack support and guidance in their learning progress and do not have chance to go to private tutors or tuition due to their poor background.

In order for Malaysia to become a contender in the global workforce, global academia, and global economy, Malaysian students need to be sufficiently proficient in the English language first through meaningful English lessons in schools (Lim, 2014). However, the low performance of English Language results in Standard Examination is imperative towards the performance of students' language proficiency. The performance for English writing in UPSR, 2017 and 2018 are the lowest among the other five subjects. The data of the 014 paper results which represent the students writing proficiency were the least in performance and quite alarming with $26.4 \%$ or 87,205 candidates failed in 2017 and the total of $25.6 \%$ or 83,735 candidates in 2018. Writing is a mode of communication that enables students to express certain emotions, opinions or information through a well-constructed text. Once children master the process of composing, new skills establish from the first basic phrases to the writing of stories and essays. The results indicated that the low achiever candidates were unable to construct simple sentences correctly due to lack of vocabulary and proficiency in the language to write a story. (Lembaga Peperiksaan Malaysia, 2017- 2018).

Due to this shortcoming, teachers and peers seem to be the closest source that they could refer to. Peer support is well known as a collaborative and cooperative learning strategy that promotes peer interaction and at the same time helps in the development of language. In addition, many peer-assisted studies have been conducted

and the results seem to support the positive impact of peer tutoring (Gersten et al., 2007). Thus, the collaboration and scaffolding with peer is seen as an approach that can be explore for teaching English among the low achiever learner especially in writing.

\section{Self and Peer Assessment Effectiveness}

Peer learning is a type of cooperative learning that encourages the importance of student engagement and results in a variety of successful (Christudason, 2003). In a group where all members of the group take responsibility not only for their own learning, but also for the learning of their peers; peer learning, collective learning, cooperative learning and collaborative learning are interchangeable. They have a common aim, which could be problem-solving, learning or gaining skills. Peer evaluation is an essential element of peer learning. The feature is in line with 21st century learning skills that emphasize communication, collaboration, creativity and critical thinking (4Cs) in teaching and learning process. Another research by ljubojević (2014) indicated that the students who engaged in group exercises demonstrated higher improvement in writing. In the final test, the participants did well when they had to compose an argumentative article. In compositional organization, the students showed positive results, primarily in using the implementation of the funnel, formulating the subject sentence and managing the concept, giving good supporting information. The form and internal pattern of their essays became clearly apparent after ten weeks of collaborative work, and interpersonal abilities were managed more adequately. 
In middle and high schools, the assessment of learning activities in curriculum has intensified exposure to self and peer grading strategies (Sanchez et. al, 2017). In parallel with the selection criteria assessments of 3rd-to 12th-level schools, this research discussed multiple problems related to the use of self and peer-grading. In comparison, other moderator analyses and study analysis showed that self- and peer-grading practices can be adapted to have a positive effect in primary and secondary schools through the use of rubrics and training for students in a formative evaluation setting. However, these mediating variables require further analysis to allow more conclusive results due to a limited number of studies. In the global education reform movement, there is also an increased trend in moving away from learning evaluation (summative and formative assessment, but to assessment as learning, where the assessment process becomes part of the learning process and students review and analyze their own learning process (Dann 2014; William 2011). Assessment and learning can be seen as one approach in which assessment becomes an integral part of their own development and learning process. (Thomas, Martin, and Pleasants, 2011).

The pedagogy of teaching in Malaysia has also evolved through the implementation of SBA and reflective teaching \& learning approach. The Curriculum-based assessment (CBA) has been applied to monitor and measure the students' proficiency and progress individually by fulfilling the SBA form from time to time. It is possible to define CBA as any collection of measurement activities that use "direct observation and recording of a student's performance in the local curriculum as a basis for gathering information to make instructional decisions" (Deno, 1987, p. 41). According to Marston (1989); Fuchs (2004), Children whose teachers used the continuous measurement and evaluation method performed better than students whose teachers used conventional methods of monitoring, Therefore, the implementation of CoSTAR module in teaching and learning hopefully would help the teacher to assess their student's progress and save their precious time too.

Introducing peer and self- assessment approaches into English teaching may be quite challenging but beneficial to strengthening the relationship between teacher feedback and students learning, encouraging student to change the way of students learning and promote lifelong learning. The present study therefore, aimed at exploring and recognizing how selfassessment and peer feedback could help the low achiever students resolve their weaknesses in second language writing skills. The outcome of this study proposes that there should be a much deeper approach to teaching English by creating more meaningful English lessons rather than the surface level approach of teaching by memorization and repetition.

\section{The Integration of Self-Peer Assessment in ESL Classroom}

Being aware of the importance of English proficiency to Malaysian learners, the Ministry of Education (MOE, hereafter) has launched various intervention programs to raise the level of English language proficiency among students in Malaysia. The Malaysian Education Blueprint Plan 2013-2025 (MEBP, hereafter) has highlighted the language goal for Malaysia's education system which is to ensure every child is proficient in Bahasa

Malaysia and English language and are encouraged to learn an additional language. To support this goal, the MOE has launched its blueprint 'English Language Education Reform in Malaysia: The Roadmap 2015-2025'. In this blueprint, the Common European Framework of Reference for Languages (CEFR) is being adopted as a course of action in improving the English Language (EL) proficiency of our students and teachers in terms of curriculum, pedagogy as 
well as assessment (English Language Education Reform in Malaysia: The Roadmap 20152025,2016, p. 5).

English learning in Malaysia is test-oriented learning. The traditional classrooms of writing in Malaysia had given so much emphasis on the end product: form, structures and grammar. The methods for assessing the students in English of our school is merely focusing on test and exam. There is only a limited formative evaluation in our teaching. Since they are passive learners, some learners do not get their desirable grades and do not have the motivation and confidence to learn English. The traditional assessment is generally good at evaluating, especially giving students the outcomes of learning, but some feedback and encouragement that students need most is often missed. It is unfair for a student to be justified by the achievement of the UPSR as the center's assessment while the process of the learning input is not taken in heed.

The curriculum restructuring from summative to formative assessment in the implementation of SBA changed the teaching practice to be more reflective and student- centred. However, there is lack of understanding, references and material towards the implementing of SBA. A study of the concern of EL teachers towards SBA by Majid (2011) has found out that although the teacher has awareness of the SBA implementation but the teachers' knowledge and skills in implementing SBA is still quite poor despite of the guidelines and objectives provided by the ministry. More hands-on sessions, such as workshops and open discussions on the challenges, teaching material and issues in implementing the assessment, need to be carried out. Hence, she suggested training focusing on time management, students' exposure to assessment and techniques or strategies can be done and helpful.

Recent changes in Malaysia education have witnessed a new scenario in the methodology of teaching and learning. As an integral aspect of the learning process, a change from teachercentered to learner-centered tacit evaluation must be incorporated into the activity or tasks during the class. Vigorous learning, cooperative learning and inductive learning are used in the student - centered approach. The responsibility of teachers is to provide an inspiring learning structure for learners by providing information and tools as well as facilitating constructivist learning experiences. (Schreurs, J., \& Dumbraveanu, R., 2014). However, in the study conducted by Sardareh (2018) entitled 'Assessment for Learning in a Malaysian ESL Primary School Context' Results found that it is erratic for the teachers to use formative feedback systematically to improve learning because they are not knowledgeable to apply the approaches effectively to improve academic performance of students in their daily teaching.

Therefore, the researcher felt that there is an urge to fulfil the gap in preparing teaching and learning material based on assessment pedagogy approach. For now, there is no specific module in current market focusing in self-assessment and peer feedback to enhance writing proficiency in Malaysian context for teachers' guidance. Hence, this

study hopefully could be contributed and bringing the gap to the development of the proposed module for the implementation of self-assessment and peer feedback approaches in primary school, in order to enhance low achiever student's writing abilities and promote language proficiency via several approaches to be employed by teachers in the classroom instruction and leads to pedagogical development in English writing in future. 
In this study, the researcher will tailor and develop a module which contribute to pedagogical development in English writing proficiency for future Malaysia ESL learner. The development of the Collaborative-Student Takes Assessment Responsibility (Co- STAR) module was intended as an example in proposing how collaborative self- assessment and peer feedback approach could be incorporated in formal learning to assist the low achievers in English Language. The GALUS (gagal lulus) and GARUK (gagal teruk) students will work collaboratively with their peers through a few sets of exercises developed based on Self-regulation Model (Butler \& Winne, 1995), SOLO taxonomy and writing skills in the MOE syllabus.

In the Kurikulum Standard Sekolah Rendah (KSSR), students are encouraged to work together and help each other rather than being focused on competing to being the best. Although academic achievement is important, it is no longer everything. Character development and values are also given prominence. Thus, the development of the Co- STAR module will not only be focusing on explicit strategy of learning but also stressed on developing the soft skills among the students through structured collaborative task with their peers. By helping their low achiever's friend, ones will also indirectly develop his/her own skills and understanding. On the other side, teachers would also benefit as it helps to make their task easier when it comes time to grade.

However, the students need to be trained and provided with active learning opportunities and materials which will help them to achieve the goals. They need explicit training to practice reflection and metacognition (Pintrich \& Schunk, 2002). Experience shows that the best useful and effective way to develop students' metacognitive abilities is to teach metacognitive strategies hand-in-hand with the learning content. Teacher should provide specific, guided prompts that consistently direct students' thinking throughout the learning activity. Therefore, researcher has designed a feedback grid rubric in the CO- STAR module as a tool in helping students to practice and improve their metacognitive skills. The LAL would work collaboratively with their partner who is more capable than them in EL.

The conceptual of self-regulation paradigm of Butler and Winne (1995) illustrated in Figure 1 has been adapted in the development of a self-assessment writing module. As one of the few feasible ones to have a theoretical formulation of feedback and self-regulation, their paradigm stands out. Seven principles of appropriate feedback practice are proposed after an analysis of the functional model; they are aligned with the model and supported by a review of the assessment and feedback research literature. Intrinsic mechanisms are represented within the shaded region of the learner. This reveals how learning and progress are controlled and managed by the learner. It also highlights the crucial role of internally generated feedback in these systems.

Pintrich \& Zusho (2002) proposed the following operational principle of self-regulation:

"Self-regulated learning is an active constructive process whereby learners set goals for their learning and monitor, regulate, and control their cognition, motivation, and behaviour, guided and constrained by their goals and the contextual features of the environment. (p. 64)"

This definition recognizes that self-regulation applies not just to cognition but also to motivational beliefs and overt behaviour. It also recognizes that there are limits to learner 
self-regulation; for example, the teacher usually devises the learning task and determines the assessment requirements. The model proposed:

\section{A) Teacher sets task (goal criteria/standard)}

The academic challenge or assignment set by the instructor in the class is used in the model as an opportunity for the student to enable self-regulation processes (shown at the centre of the diagram). Obligation to perform a task allows a student to draw on prior knowledge and motivational values.

\section{B) Domain knowledge, Strategy knowledge, motivational and belief}

Teacher construct a personal interpretation of the meaning of the task and its requirements. Based on this internal conception, the student formulates his or her own task goals. A personal description of the significance of the task and its specifications is constructed by the teacher. Each student formulates his or her own goal tasks based on this internal conception.

\section{C) Student goal}

Typically, the student's interests with those of the instructor will clash, but the difference might not be large (e.g., if the student wishes only to pass the assignment). The priorities of the student can also be ambiguous rather than simple (e.g., a vague intention or task orientation). However, these goals can help to shape the strategies and approaches.

\section{D) Tactics and strategy}

After getting information about the task performance, student may re-examine their tactic and strategy to achieve the expected of the targeted progress. In the low achiever case or at the primary level, the teacher plays important role to modify their teaching and learning approaches to suit with the student's requirement.

\section{E) Internal learning outcomes}

Internal effects refer to changes that occur in cognitive or affective/motivational phases during task participation (e.g., increased understanding, changes in self-perceptions of ability).

\section{F) Externally observable outcomes}

The externally measurable effects apply to the concrete goods and practices formed (e.g., essays) (e.g., student presentations).

\section{G) External feedback by teacher or peer}

External feedback to the student in the model can be provided by the instructor, peer or others (e.g., a relief teacher or a computer). This additional information could expand, align or contrast with the student's comprehension of the assignment and the course of learning. However, to create an effect on internal processes or external effects, the student must constantly interact with these external inputs. In effect, if they were to have a major impact on future learning, the teacher's input responses would have to be understood, constructed and internalized by the student (Ivanic et al., 2000). For non-native speaker students at the primary level, it is suggested for the teacher to provide a list of responses that can be marked by peer. The engagement likewise would lead them to self-generated feedback of themselves and revise his or her domain knowledge or motivational beliefs which, in turn, might influence 
subsequent self-regulation.

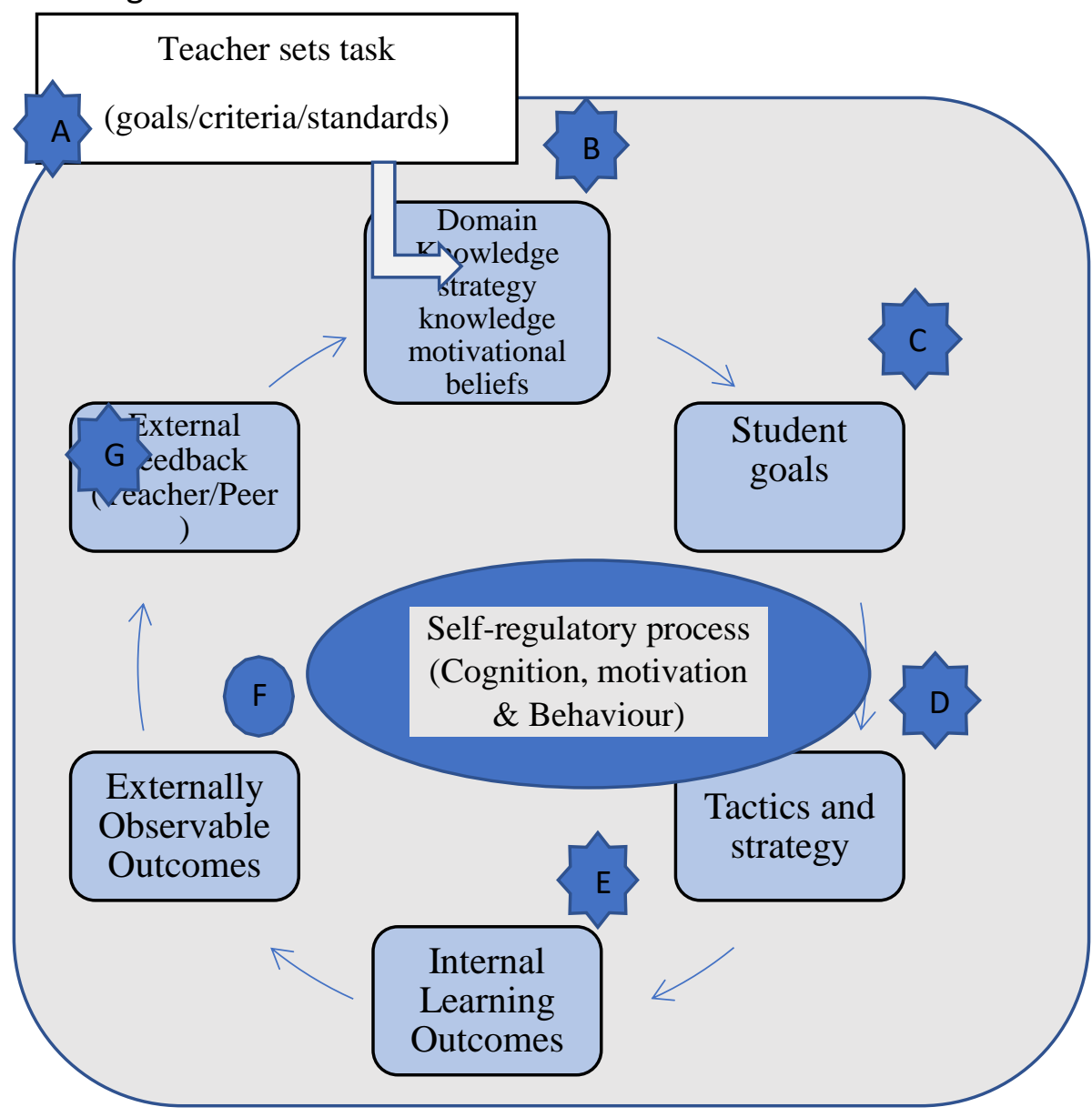

Figure 1: A model of self-regulated and the feedback principles that support and develop self-regulation in students. (Butler \& Winne, 1995)

The process of the concept model above underlying the development of the Co- STAR module which emphasized the internal and external outcomes of the self and peer assessment practice. The format of this module consists four range of levels from beginner to advance in order to help the students' progress in their essay writing. The progress tracker column is set out as an explicit motivation goals for the student's self-evaluation. It is also as a resource for the teachers to track their student's understanding and gear their lesson based upon this information. The writing editing checklist is a guideline and as a tool for the student and peer to assess their writing product. Researcher believes through systematic learning activities and assessment proposed in the module would help the LAL to improve their essay writing thus achieve better grade. Besides, it also triggered positive motivation and selfesteem which encourage independent and self -regulated learning in future.

\section{Conclusion}

The review of this study is expected to provide information and awareness to teachers about the importance of self - assessment and peer feedback approach in enhancing students' achievement. The social and interpersonal relationship skills will also develop through the collaborative method as well as the leadership skills of the future. To succeed, students must learn to communicate with others within the fun range of social situations, especially situations involving fluid social structures, human diversity, and interdependence. 
With this self and peer assessment approach and self-regulation model proposed in the CoSTAR learning module, teachers will have a guidance and effective teaching tool to a more organized teaching instructional and sources to ensure the low achievers achieved the objective of the writing syllabus. Besides, it is a need for the teacher to revise their theories of classroom learning and approaches to pedagogy to adapt with the $21^{\text {st }}$ century learning styles. Last but not least, the module hopefully will be contributed to the body of knowledge in the ESL teaching and learning in Malaysia and other countries with the similar background. The findings are also expected not only to help students improve their writing skills but social interactions as well in arousing their interest in learning English.

\section{Corresponding Author}

Prof. Madya Md. Nasir Bin Masran

Faculty of Human Development,

Universiti Pendidikan Sultan Idris, 35900 Tanjong Malim, Perak, Malaysia.

Email: m.nasir@fpm.upsi.edu.my

\section{References}

Boud, D. (2013). Enhancing learning through self-assessment. Routledge.

Brew, A. (1999). Towards autonomous assessment: using self-assessment and peer assessment. Assessment matters in higher education: Choosing and using diverse approaches, 159-171.

Brown, G. T., \& Hattie, J. (2012). The benefits of regular standardized assessment in childhood education. Contemporary debates in childhood education and development, 287-292.

Butler, D. L., \& Winne, P. H. (1995). Feedback and self-regulated learning: A theoretical synthesis. Review of educational research, 65(3), 245-281.

Christudason, A. (2003). Peer learning. Successful Learning, 27. Retrieved from http://www.cdtl.nus.edu.sg/success/sl37.htm

Deno, S. L. (1987). Curriculum-based measurement. Teaching Exceptional Children, 20(1), 4042.

Falchikov, N. (2013). Improving assessment through student involvement: Practical solutions for aiding learning in higher and further education. Routledge.

Fuchs, L. S., Deno, S. L., \& Mirkin, P. K. (1984). The effects of frequent curriculum-based measurement and evaluation on pedagogy, student achievement, and student awareness of learning. American Educational Research Journal, 21(2), 449- 460.

Gersten, R. M., Baker, S. K., \& Edwards, L. (1999). Teaching expressive writing to students with learning disabilities. Reston, VA: ERIC Clearinghouse on Disabilities and Gifted Education.

Huang, S., Eslami, Z., \& Hu, R. J. S. (2010). The Relationship between Teacher and Peer Support and English-Language Learners' Anxiety. English Language Teaching, 3(1), 32-40.

Jalaluddin, N. H., Norsimah, M. A., \& Kesumawati, A. B. (2008). The mastery of English language among lower secondary school students in Malaysia: A linguistic analysis. European Journal of Social Sciences, 7(2), 106-119.

Laal, M., \& Ghodsi, S. M. (2012). Benefits of collaborative learning. Procedia-social and behavioral sciences, 31, 486-490.

Lim, T. D. (2013). Analysing Malaysian English Classrooms: Reading, Writing, Speaking and Listening Teaching Strategies (Doctoral dissertation, University of Washington). 
Ljubojević, D. A. N. I. J. E. L. A. (2014). Implementing peer assessment tools to enhance teaching writing. Зборник радова са 5. међународне конференције eLearning, 131134.

Ministry of Education Malaysia. (2015). English Language Education Reform in Malaysia: The Roadmap 2015-2025. English Language Standards and Quality Council.

Misbah, N. H., Mohamad, M., Yunus, M. M., \& Ya'acob, A. (2017). Identifying the Factors Contributing to Students' Difficulties in the English Language Learning. Creative Education, 8(13), 1999-2008.

Nielsen, K. (2014). Self-assessment methods in writing instruction: a conceptual framework, successful practices and essential strategies. Journal of Research in Reading, 37(1), 116.

Pintrich, P. R., \& Schunk, D. H. (2002). Motivation in education: Theory, research, and applications. Prentice Hall.

Rajkamal, A \& Prema, N. (2018). Effectiveness of Counselling on Academic Achievement of Low Achievers. International Journal of Environmental and Science Education, 13(1), 11 16.

Sardareh, S. A. (2018). Formative feedback in a Malaysian primary school ESL context. MOJES: Malaysian Online Journal of Educational Sciences, 4(1), 1-8.

Schreurs, J., \& Dumbraveanu, R. (2014). A shift from teacher centered to learner centered approach. International Journal of Engineering Pedagogy, 4(3),36-41.

Topping, K. J. (2009). Peer assessment. Theory into practice, 48(1), 20-27. 